\title{
The use of contrast media
}

\section{Mark O. Baerlocher MD, Murray Asch MD, Andy Myers MD}

Previously published at www.cmaj.ca

\begin{abstract}
All contrast agents are not equal
The two main types of iodine-based contrast media are ionic and nonionic. The development of ionic contrast media in the 1920s and 1930s allowed radiologists to visualize vessels and organs on various imaging studies. However, these have some degree of toxicity, and the introduction of nonionic media in the 1970s led to fewer adverse reactions. ${ }^{1}$ Newer contrast media include low-osmolar ionic, isoosmolar and gadolinium-based media. The last type is used in magnetic resonance imaging.
\end{abstract}

A previous adverse reaction to intravascular contrast media increases the risk of a subsequent reaction

The risk of a subsequent adverse reaction is $17 \%-35 \%$ with ionic contrast media and $5 \%$ with nonionic media.

High-osmolar ionic contrast media should not be used intravascularly

High-osmolar ionic contrast media are no longer used intravascularly because of the increased risk of adverse reactions. Safer, low-osmolar ionic formulations are now available. Although higher costs limited the widespread use of nonionic agents in the past, the cost differential is now low. ${ }^{4}$ There are only limited data available on the use of isoosmolar contrast agents.

\section{Adverse reactions are more common with ionic contrast media}

Nonionic contrast media are well tolerated and have a better safety profile than ionic agents (Table 1)., ${ }^{2,3}$

Table 1: Incidence of adverse reactions to contrast media administered intravascularly ${ }^{2,3}$

\begin{tabular}{lcc}
\hline & \multicolumn{2}{c}{$\begin{array}{c}\text { Contrast media; } \\
\text { incidence, \%* }\end{array}$} \\
\cline { 2 - 3 } Type of reaction & Nonionic & lonic \\
\hline Mild (e.g., nausea, vomiting, mild urticaria, mild pallor) & 3 & 15 \\
$\begin{array}{l}\text { Moderate (e.g., severe vomiting, extensive urticaria, } \\
\text { laryngeal edema, dyspnea, rigors) }\end{array}$ & $0.2-0.4$ & $1-2$ \\
$\begin{array}{l}\text { Severe (e.g., pulmonary edema, tissue necrosis, cardiac } \\
\text { arrythmias/arrest, circulatory collapse, loss of consciousness) }\end{array}$ & 0.04 & 0.20 \\
\hline $\begin{array}{l}\text { Death } \\
\text { *Unless stated otherwise. }\end{array}$ & $1: 170000$ & $1: 170000$ \\
\hline
\end{tabular}

\section{Avoid oral administration of ionic contrast media}

If aspirated, ionic contrast media are much more likely than nonionic media to be associated with adverse reactions. Reactions in the lungs include bronchospasm, pulmonary edema, increased pulmonary vascular resistance and histamine release from lung mast cells and basophils. ${ }^{5}$ Avoid using ionic agents in endoscopy of the upper gastrointestinal tract or when checking chest drains or assessing the position of nasogastric feeding tubes.

This article has been peer reviewed.

Competing interests: None declared.

From the Department of Medical Imaging (Baerlocher), University of Toronto, Toronto, Ont., and the Department of Radiology (Asch, Myers), Lakeridge Health Corporation, Oshawa, Ont.

\section{REFERENCES}

1. Namasivayam S, Kalra MK, Torres WE, et al Adverse reactions to intravenous iodinated contrast media: a primer for radiologists. Emerg Radiol 2006;12:210-5.

2. Morcos SK, Thomsen HS Adverse reactions to iodinated contrast media. Eur Radiol 2001;11 1267-75

3. Thomsen HS, Bush WH. Adverse effects of contrast media: incidence, prevention and management. Drug Saf 1998;19:313-24.

4. Thomas SM, Williams JE, Adam EJ. Intravascular contrast media: Can we justify the continued use of ionic contrast agents? Clin Radiol 1997;52:59-61.

5. Morcos SK. Effects of radiographic contrast media on the lung. Br J Radiol 2003;76:290-5.

For more information on the use of contrast media, see the American College of Radiology Manual on Contrast Media at www.acr.org /contrast-manual.

"Five things to know about ..." is a new series that presents key statements on topics of interest to physicians. For author instructions, go to cmaj.ca. 